\title{
The role of public loans in financing business R\&D through the economic cycle
}

\section{Ascensión Barajas $^{1} \cdot$ Elena Huergo $^{2,3}$ [D $\cdot$ Lourdes Moreno $^{2}$}

Received: 11 May 2020 / Accepted: 12 March 2021 / Published online: 26 March 2021

(c) Springer Nature Switzerland AG 2021

\begin{abstract}
Should governments increase their efforts in $\mathrm{R} \& \mathrm{D}$ public funding during recession periods? The objective of the present study is to compare the effect of public aid to business R\&D on technological inputs and outputs through the economic cycle. We contribute to this literature by examining the effect of one specific instrument of direct public support: selective loans for firms' R\&D projects. For the analysis, we consider Spanish firms supported through this kind of instrument for the periods 2002-2005 and 2010-2012. Our results suggest that the hypothesis of full crowding out of private $R \& D$ is rejected in both cycle periods, expansion and recession: public support has positive effects on the resources devoted to R\&D activities. However, the effect of public support on some technological outputs depends on the cycle phase: firms supported by selective loans during the crisis are more likely to obtain product innovations.
\end{abstract}

Keywords Impact assessment $\cdot$ Economic crisis $\cdot$ Public aid $\cdot$ Business R\&D

JEL Classification $\mathrm{H} 81 \cdot \mathrm{L} 2 \cdot \mathrm{O} 3$

Elena Huergo

ehuergoo@ucm.es

Ascensión Barajas

abi@cdti.es

Lourdes Moreno

lmorenom@ucm.es

1 Unit of Impact Assessment, CDTI (Centre for the Development of Industrial Technology), C/ Cid 4, 28001 Madrid, Spain

2 GRIPICO (Group for Research in Productivity, Innovation and Competition), Universidad Complutense de Madrid, Madrid, Spain

3 ICAE (Instituto Complutense de Análisis Económico), Universidad Complutense de Madrid, Madrid, Spain 


\section{Introduction}

Endogenous growth theory (Romer 1990) places technological capital as an engine of growth in the long term, subject to the decisions of agents. To the extent that technology is no longer considered an exogenous factor, we admit that the business cycle can also affect R\&D investment. A relevant question is whether this impact will be positive or negative.

From a theoretical point of view, during recessions, the allocation of firms' resources would tend to be more efficient (opportunity cost effect), concentrated on activities that generate higher returns in terms of long-term productivity. Therefore, if a company increases $R \& D$ expenditures to strengthen its competitiveness, the effect on its productivity should be positive. However, this cost opportunity effect might be compensated in the context of an imperfect capital market with financial constraints (Aghion et al. 2010). Most of the empirical literature is consistent with this second argument. In times of recession, R\&D investment behaves counter-cyclically in firms that have enough resources to fund it, while the opposite happens if companies have difficulties accessing external financing (Aghion et al. 2012; BovhaPadilla et al. 2009; López-García et al. 2013).

From this perspective, the role of public funding could be decisive as long as it mitigates the negative effect of financial constraints during the crisis. Notice that firms' financial constraints are also important for agencies that award aid, as the main justification for public intervention is the presence of R\&D-related market failures, which are associated with: (1) the incomplete appropriability of technological results due to knowledge spillovers and the existing gap between private and public return, and (2) the cost of capital when the innovation financer and the investor are not the same agents. In this sense, both the conditions and the effects of public support can be affected by the business cycle.

Therefore, an additional and key question is whether the impact of public aid differs over the business cycle and is less or more effective in adverse economic conditions. Before the recent financial crisis, the hypothesis of full crowding out of private R\&D was rejected in most previous empirical analyses (Becker 2015; David et al. 2000; Dimos and Pugh2016; García-Quevedo 2004; Zúñiga-Vicente et al. 2014). The scarce studies that analyse the effects of public support during the crisis focus mainly on public subsidies and offer heterogeneous results. Hud and Hussinger (2015) find a crowding out effect during the year 2009 for German firms. Aristei et al. (2017) reject both full and partial crowding out using firm-level data from France, Germany, Italy, Spain and the UK. However, they do not find evidence of additionality in any of the countries. For Spanish firms, Busom and Vélez-Ospina (2020) find that the effect of public support depends on the stage of the cycle, the duration of the support and the type of outcome indicator.

The objective of the present study is to contribute to this literature by analysing the effect of one specific instrument of direct public support: selective loans 
for firms' R\&D projects. ${ }^{1}$ The impact of this instrument may be different from the impact of subsidies during recessions at least for two reasons. First, the reimbursable character of loans makes them less attractive than subsidies for firms with highrisk projects because companies may have problems paying the principal back in the case of project failure. These problems could be even higher during recessions if the economic situation makes it more difficult for firms to profit from technological outcomes. Therefore, firms might show a lower propensity to apply for public loans in downturns than in upturns. Secondly, loans are also expected to impose more discipline on awarded firms than subsidies because loan programs usually imply more monitoring of project development by public agencies, which results in more efficiency that turns in a higher generation of innovations (Huergo and Trenado 2010). This monitoring may increase in downturns because public aid for R\&D must compete in public budgets with other public spending items and, consequently, policy makers are expected to develop a more efficient implementation of R\&D support.

For our objective, we use information provided by the Centre for the Development of Industrial Technology (CDTI). This organism is the main public agency in Spain that grants financial aid of its own to companies for the execution of R\&D projects. We combine information about firms supported through CDTI programmes for the periods 2002-2005 (years of expansion) and 2010-2012 (years of recession) with data provided by the Spanish Institute of Statistics (INE) about non-supported firms from the Spanish Technological Innovation Survey (the Spanish version of the CIS). Although the main objectives of CDTI loan programmes have remained constant during the last few decades, funding conditions and requirements on guarantees have partially changed between the two periods considered for our analysis. These changes basically consist of improving funding conditions while at the same time asking for more real guarantees in the years of recession. Therefore, one additional contribution of our paper is that we examine whether these changes in the design of the support programme made to face the economic crisis favour the maintenance of innovation results during the downturn.

In our analysis, we focus on the effect of public loans not only on R\&D expenditures, but also on a wide set of innovation inputs and outputs. Impact assessment is conducted using "matching" techniques. Our results suggest that public support has a positive effect on the resources devoted to $R \& D$ activities regardless of the phase of the cycle. However, although there is output additionality through the business cycle, the effect on technological outputs differs: during the expansion (crisis) period, firms are more likely to obtain process (product) innovations. One distinguishing feature of our results is that they have been interpreted in coherence with the evolution of the instrument and taking into account the objectives of the policy makers. Therefore, conclusions could be applied to the design of public programmes, especially in recession periods.

\footnotetext{
${ }^{1}$ Following Colombo et al. (2011), we use the adjective "selective" to denote that the loan is granted by the public agency through a competitive procedure that requires an ex-ante evaluation of the R\&D project.
} 
The rest of the paper is organised as follows. Section 2 reviews the related literature. Section 3 summarises the main characteristics of CDTI programmes before and during the crisis. Section 4 describes the empirical model and the data. In Sect. 5, we present the results and, finally, Sect. 6 concludes.

\section{Related literature}

As we mentioned in the Introduction, our paper is related to at least two strands of the literature: studies about the behaviour of firms' innovation inputs and outputs and evidence about the role of public aid to firms' $R \& D$ projects through the economic cycle. The cyclicality of business $R \& D$ expenditure is a complex issue that involves many factors. Most theoretical approaches explain this cyclicality by the change in the opportunity cost of $R \& D$ expenditures in contexts with or without credit constraints. Within the Schumpeterian growth literature, during recessions, the allocation of firms' resources would tend to be more efficiently concentrated on activities that generate higher returns in terms of long-term productivity. ${ }^{2}$ This implies that R\&D investment will be counter-cyclical because the opportunity cost between physical capital investment and $R \& D$ expenditure increases during the crisis.

The model of Aghion et al. (2010) supports this idea in a context of perfect capital markets without financial constraints. In their model, they distinguish between short-term and long-term investments. As the horizon time of R\&D investment is longer, the relative opportunity cost between capital and R\&D investment changes over the business cycle and the share of $R \& D$ expenditures should increase during recessions. However, this opportunity cost effect might be compensated in the context of an imperfect capital market with financial constraints. Although credit restrictions affect both short-term and long-term investments, the liquidity risk of $\mathrm{R} \& \mathrm{D}$ investments is larger and $\mathrm{R} \& \mathrm{D}$ expenditures would become pro-cyclical.

The model proposed by Barlevy (2007) also provides a pro-cyclical behaviour of firms with respect to the introduction of innovations. This behaviour is not related to financial restrictions, but to the incomplete appropriability of technological results due to knowledge spillovers. Barlevy's argument is that the losses from involuntary spillovers to competitors are lower during economic prosperity. In his model, R\&D expenditures and product innovations will be higher in the booms because the profits of appropriable returns are bigger.

In a recent study, Mand (2019) proposes a new mechanism for explaining the pro-cyclicality of R\&D. He develops a real business cycle model with endogenous innovation, but uses a specification that allows for multiple inputs including scientists, staff and final goods which complement each other. As goods are scarcer in

\footnotetext{
${ }^{2}$ Also related to the Schumpeterian growth literature, there is long-standing research that analyses the role of innovation over the business cycle and over long waves of technical change (Rosenberg and Frischtak 1984; Perez 2010). This research provides arguments for understanding the influence of technical change and technological revolutions on long-term economic growth and economic cycles.
} 
recessions than in booms, the complementarity of $\mathrm{R} \& \mathrm{D}$ inputs dampens the reallocation of labour implied by the opportunity cost argument.

The empirical literature typically confirms a pro-cyclical behaviour of R\&D expenditures in the presence of financial constraints (Aghion et al. 2012; BovhaPadilla et al. 2009; López-García et al. 2013; Männasoo and Meriküll 2014). In particular, using data for French firms during the period 1993-2004, Aghion et al. (2012) find that, in times of recession, R\&D investment behaves counter-cyclically in firms that have enough resources to fund it, while the opposite happens if companies have difficulties accessing external financing. Similarly, Männasoo and Meriküll (2014) find that credit constraints have a strong and adverse effect on the propensity to undertake R\&D in the case of firms from new member countries of the European Union in Central, Southern, and Eastern Europe for the years 2001, 2004 and 2007. Firms' sales growth has a direct negative effect on R\&D, an indirect positive effect by mitigating the credit constraints on firms, and a total positive effect. Therefore, the authors argue that the pro-cyclicality of R\&D in terms of firm sales growth, often found in the empirical literature, may be driven by alleviated credit constraints and not by firms' intention to focus on R\&D during booms.

However, there are also analyses that point out the relevance of other variables to qualify the relation between financial constraints and business R\&D investments during the economic cycle. This is the case of Beneito et al. (2015), who find that the pro-cyclical effect of financial constraints is lower if the company is family-owned or if it belongs to a business group because of the greater availability of internal resources for financing $R \& D$ activities. In fact, in times of recession, R\&D investment behaves counter-cyclically in these firms. Similarly, Laborda et al. (2020) find that the effect of the business cycle on the perception of external financial constraints is subject to the availability of internal funds in each firm. The sensitivity of firms' R\&D expending is procyclical in firms with high cash flows and countercyclical in firms with low cash flows.

An alternative and complementary argument that explains the pro-cyclicality of R\&D investment is tested by Fabrizio and Tsolmon (2014) using information for a panel data set of 7754 US firms across 100 manufacturing industries. These authors claim that "R\&D investment is pro-cyclical because firms strategically time their innovations to coincide with economic booms, when high demand makes it possible to capture more rents than during periods of lower demand" (page 662). This pro-cyclicality of $\mathrm{R} \& \mathrm{D}$ investments and innovation outcomes would depend on industrial structure, as the value of innovations may decrease more quickly in industries with faster rates of obsolescence. Their results are consistent with this prediction even after controlling for the extent of financial constraints. R\&D spending is more pro-cyclical in industries with faster obsolescence, where matching invention to demand is more valuable, and innovation is more pro-cyclical in industries with weaker intellectual property protection.

In a different context, using data from two waves of the UK Community Innovation Survey, Archibugi et al. (2013) analyse the behaviour of firm innovation investment during the 2008 financial crisis. They find that the firms' whole investment declines during the crisis, reflecting a pro-cyclical behaviour, although a small but relevant group of firms increase their expenditures on innovation. They use this 
heterogeneity to test Schumpeterian hypotheses about creative destruction or creative accumulation processes. If firms which innovated before the financial crisis respond to the crisis by continuing to innovate, regardless of the business cycle, the process of creative accumulation would be supported. On the contrary, if firms not involved in innovation before the financial crisis respond to the crisis by innovating, the behaviour would be in accordance with the creative destruction process. Their analysis provides evidence that the crisis led to a concentration of innovative activities within a small group of fast-growing new firms and firms that were already highly innovative before the crisis. In this sense, their results are consistent with an innovation environment characterised by the presence of both creative destruction and creative accumulation.

Apart from the behaviour of R\&D expenditures, other authors also find different behaviour of innovation outputs over the cycle although the evidence with firm-level information is scarce and not conclusive. ${ }^{3}$ Using data from several waves of European Community Innovation Surveys for more than 20 countries, Peters et al. (2014) find that the introduction of products that are new to the firm but not to the market increases during recessions, while the introduction of innovations new to the market rises in booms. Archibugi et al. (2013) find firms that introduce new product and market developments to better face the crisis. However, process innovations do not appear to be sensitive to the cycle. Lööf and Nabavi (2016) use panel data of Swedish firms during the period 1997-2007 to test the impact of financial constraints on patent applications and other performance indicators. They find that patents are negatively affected by financing restrictions only in high-tech sectors, regardless of the phase of the cycle.

Our paper is also related to the strand of the recent empirical literature on the role of public support to firms' R\&D projects during the economic crisis. Although it is increasing, there is still scarce evidence about how the business cycle affects public R\&D expenditures. The role of public funding could be decisive as long as it mitigates the negative effect of financial constraints during the crisis if it behaves counter-cyclically. However, the crisis can negatively affect public R\&D expenditures if governments have to cut spending. Additionally, a key question is whether the impact of public aid differs over the business cycle and whether itis more/less effective in adverse economic conditions.

The evidence about how the recent economic crisis has affected public R\&D expenditures is not conclusive. Makkonen (2013) finds a pro-cyclical reaction on governments' science and technology budgets of the majority of the 27 EU countries. Brautzsch et al. (2015) show that the German economy follows a countercyclical behaviour. Applying the open input-output model, they find that the German R\&D programme counteracts the decline of GDP by half a percentage point in the year 2009. More recently, Censolo and Colombo (2017) and Pellens et al. (2018) find heterogeneity in the behaviour among European countries. Censolo and

\footnotetext{
3 With industry-level data on Germany, France, Italy, Spain, the Netherlands and the United Kingdom for the period 1995-2010, Guarascio et al. (2015) find that the positive impact of demand on the share of new product innovators during the years of expansion turns negative during the downswing.
} 
Colombo (2017) analyse the correlation between the R\&D share of total investment and GDP growth in 25 European countries over the period 1999-2014, distinguishing between core, periphery and recent countries. They find that only core countries behaved counter-cyclically over the crisis to mitigate the persistence of the recession. However, for periphery and new EU member countries, there is evidence of a pro-cyclical pattern of R\&D share over the evolution of GDP growth that could negatively affect the long-term growth of these economies. Pellens et al. (2018) confirm these results for a sample of 26 OECD countries over the period 1995-2015. While European innovation leaders and non-EU countries follow a counter-cyclical strategy, innovation followers and moderate innovators behave pro-cyclically.

The empirical evidence about how the effects of public support can be affected by the business cycle is also scarce. Using German firm data over the period 2006-2010, Hud and Hussinger (2015) show that there is evidence of a crowding out effect during the crisis year 2009. In 2010, when the German economy started to recover, the subsidy effect was smaller than in pre-crisis years, but still positive and significant. The temporary crowding out effect could be explained by the behaviour of SMEs during the crisis - reluctance to invest in R\&D-rather than by Germany's countercyclical innovation policy or by a lower average "quality" of subsidized firms in the crisis years due to the expanded subsidy program.

Aristei et al. (2017) use firm-level data from five European Union countries (France, Germany, Italy, Spain and the UK) during the period 2007-2009 to analyse the impact of both direct and indirect support on total and private (net of subsidies) R\&D expenditure over sales. This allows them to test both the hypotheses of full/partial crowding out and crowding in/additionality. While the hypothesis of full crowding out is rejected for all countries, there is no evidence of additionality in any of them. In this sense, their results suggest that direct support has helped firms maintain R\&D activities but has not generated additionality during the recession.

For Spanish firms, the evidence is slightly more positive. Cruz-Castro et al. (2018) analyse the probability of companies' abandoning in-house R\&D during the crisis and its relationship to regional and policy factors. They find that those firms receiving regional public financial support prior to the onset of the economic downturn display a lower probability of abandoning innovation activities. However, regional government $\mathrm{R} \& \mathrm{D}$ support only reduces $\mathrm{R} \& \mathrm{D}$ abandonment rates in regions where a strong system of knowledge exploitation is in place.

Also for Spain, Busom and Vélez-Ospina (2020) analyse the impact of direct support to business R\&D over the business cycle using firm-level data for the period 2005-2014. They find that treatment effects are heterogeneous. The effect of public support depends on three factors: the stage of the cycle, the sequence of participation spells (the duration of the support) and the type of outcome indicator. The effect on R\&D investment is pro-cyclical. In addition, the additionality effect is higher during recessions for firms that have sustained innovation activities and are likely to participate for more than one year. When they consider a firm's allocation of human resources, the impact of public aid is counter-cyclical: firms receiving support have assigned more employee time to innovation activities.

In sum, empirical studies about the effects of public support on the economic cycle are still scarce and provide evidence of heterogeneous impacts. Some 
researchers offer evidence of crowding-out effects during the crisis (Hud and Hussinger 2015), while others reject the hypothesis of full crowding out (Aristei et al. 2017) or even find higher additionality effects during recessions for specific types of firms (Busom and Vélez-Ospina 2020). These previous studies focus on the effects of direct public support on R\&D inputs. Our paper advances this literature by also investigating the effects of public support on innovation outputs. In addition, while the type of public support examined in previous papers consists mainly of subsidies, we focus on the specific impact of public R\&D soft loans.

\section{CDTI projects}

In recent decades, around 30\% of innovative Spanish companies had access to direct public support to finance their R\&D expenditures (Eurostat 2021). This support comes basically from the central government and, to a lesser extent, from regional administrations. In addition, a small percentage of innovative firms also get finance from the European Union (EU). The CDTI channels most of the direct R\&D support from the central government through loans at a preferential (below market) interest rate. $^{4}$

Specifically, in this study, we focus on R\&D business projects funded with selective loans by the CDTI in two periods: 2002-2005 and 2010-2012, which correspond respectively to periods of expansion and recession (see Table 1). The financial crisis strongly affected the Spanish economy. During the first years of the 2000s, the Spanish GDP had been growing above $3 \%$. This greatly reduced the unemployment rate to $8.2 \%$ in 2007 . However, during the crisis, the unemployment rate increased again and peaked in $2013(26.1 \%)$.

In both periods, CDTI programmes were targeted to the creation or significant improvement of a production process, product or service. Through these programmes, financial support is primarily provided in the form of loans, granted at an interest below market rate and with a reimbursable period of 10 years, regardless of the firm activity sector and size. ${ }^{5}$ The projects could be developed by one single firm or in collaboration with other organisations and may have a non-reimbursable part (a grant).

In general, the CDTI annually finances about 1000 projects in which more than 850 companies are involved, $60 \%$ of which are SMEs. Funding is offered throughout the year so that companies can submit a funding application linked to a project proposal at any time. The average eligible budget of a project financed by the CDTI is approximately $600,000 €$ and its duration may vary from 12 to 36 months.

Eligible costs include salaries (researchers, technicians and other supporting staff); costs of instruments and equipment; contractual research costs; technical

\footnotetext{
4 Spanish firms can also benefit from indirect support through a very generous scheme of tax incentives (Busom et al., 2014), but, unfortunately, we do not have information about this policy instrument in our databases.

5 In most years, the interest rate was equal to zero.
} 


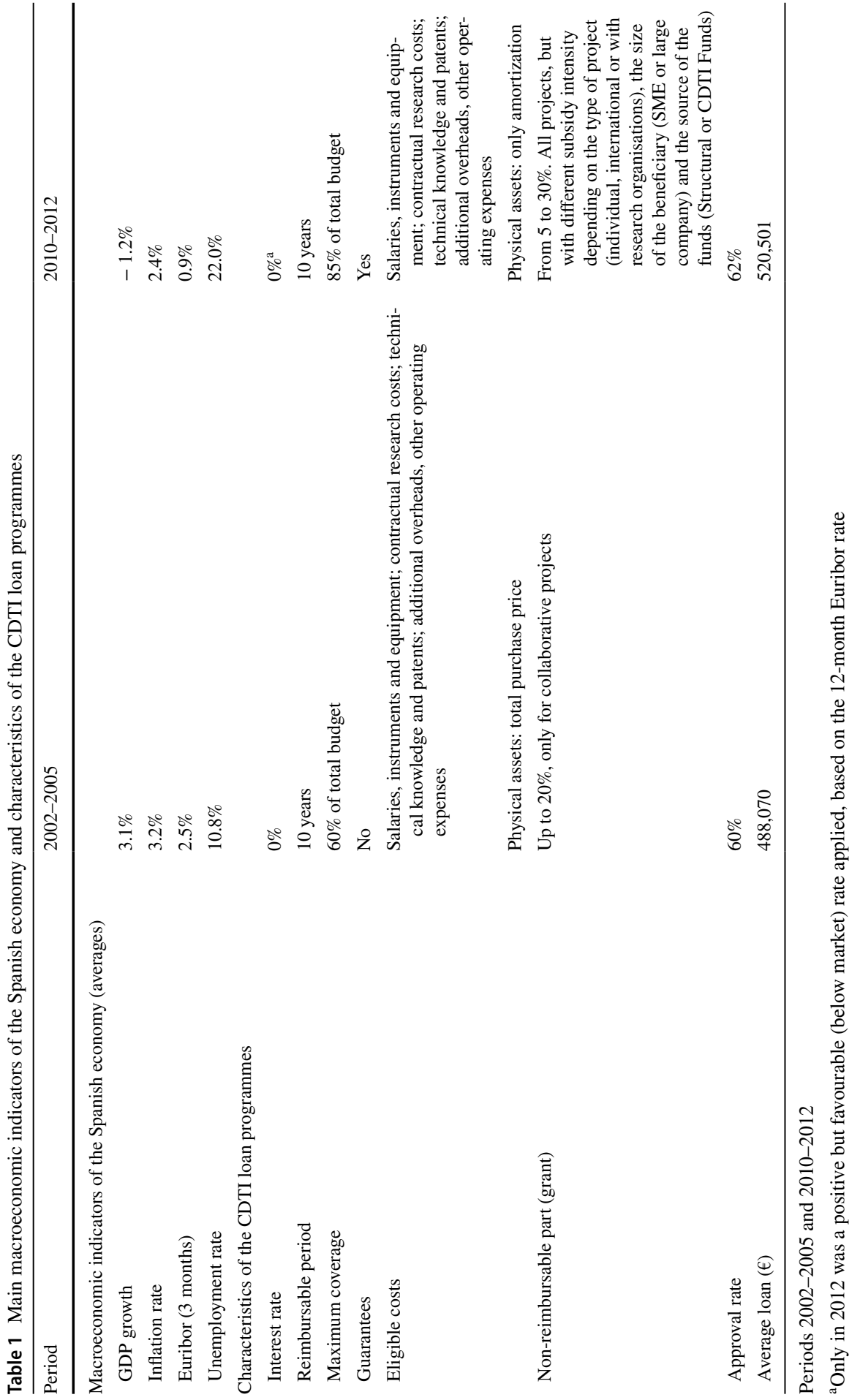


knowledge and patents bought or licensed from outside sources at market prices; additional overheads incurred directly as a result of the research project; and other operating expenses, including costs for materials, supplies and similar products, which result directly from the research project.

In order to assess the impact of these programmes, their objectives should be taken into account. These objectives are aligned with the overall mission and goals of the CDTI:

- Increasing private innovation expenditure in Spain. The purpose is to encourage firms to engage in R\&D. The CDTI requires beneficiaries to contribute with their own resources to the total project budget so that the company guarantees the co-financing and an adequate capacity of project execution.

- Promoting growth and business competitiveness. With the CDTI's funding, companies should be able to improve the competitiveness of their products and services.

- Achieving high-quality and innovative R\&D projects. The CDTI carries out a technical and thorough evaluation of the projects which apply for aid to guarantee the innovative component and the high quality of the research activities as well as the use of new leading technologies.

- Commercial approach and market-oriented projects. The main aid instrument (loan) is best suited for these projects, as it enables companies to notably speed up their work and enter target markets.

The results of R\&D activities may facilitate international technological cooperation and exports and investments abroad. Cooperation between companies, research organisations and other economic agents in the field of $\mathrm{R} \& \mathrm{D}$ and innovation is also to be encouraged.

Although these objectives have remained constant in recent decades, funding conditions partially changed between the periods 2002-2005 and 2010-2012. In particular, as can be seen in Table 1, the maximum percentage of the approved project costs covered by the loan increased from $60 \%$ in the first period up to $85 \%$ in the second. Furthermore, as of 2008, CDTI funding only covered the amortisation of physical assets (equipment, machinery, etc.) related to the project and not their total purchase price. ${ }^{6}$ In addition, during the first period, the non-reimbursable part of the loan was provided only to collaborative projects, while in the second period it was available for every project, with a different subsidy intensity depending on the type of project, the size of the beneficiary and the source of the funds.

Changes in funding conditions in the period 2010-2012 also came with new requirements on guarantees. Specifically, firms that carried out around $20 \%$ of the supported projects during those years were asked for real guarantees. ${ }^{7}$ These

\footnotetext{
6 This change is the result of the application of the COMMISSION REGULATION (EC) No 800/2008, General Block Exemption Regulation.

7 The CDTI aid scheme is based on the re-allocation of reimbursements from loans. For this reason, the sustainability of the scheme requires dealing with the failure rate of those reimbursements. In this sense, guarantees might be considered a tool for reducing this failure rate to some extent.
} 
differences in the features of CDTI programmes between periods will be taken into account when interpreting the results in Sect. 4. Note, however, that despite the different economic situation in both periods of analysis, the approval rate and the average loan of the programmes were quite similar, even slightly larger in the years of recession.

It is also important to take into account that all applications are evaluated according to specific criteria that include the degree of innovation of the proposal, the technical and financial capability to undertake the project, the ability to exploit the results, the potential market of the developments, and the fulfilment of the encouraging effect. Once R\&D projects are selected, the CDTI monitors their development, verifying that awarded projects meet the technological objectives and that the budget is correctly executed.

\section{Empirical model and data}

Following the literature on impact assessment of public aid, the implicit question to answer is what the behaviour of a funded firm would have been if it had not received public support. Notice that each firm can only be observed in the status of either being supported or not. Therefore, to measure the effect of public aid on innovative performance, we have to take into account that participation within the funding programme probably depends on the same firm characteristics that determine its innovative performance.

To solve these problems of selection and endogeneity, econometric literature has developed several methodologies (Cerulli 2010; Cerulli and Potì 2012; Heckman 1979). One of the most used methods is the matching procedure, which does not require any functional form or a distributional assumption on the errors of the equations for technological inputs and outputs. If the conditional independence assumption holds (that is, all firm characteristics that explain selection into a public funding programme are observed), the average effect of public support or treatment can be estimated by the mean difference in the outcomes of treated firms and a comparable' control group of non-supported firms. Following Rosenbaum and Rubin (1983), this control group can be selected based on propensity scores of receiving the treatment. Nevertheless, in the presence of unobservable factors that affect the likelihood of receiving a CDTI funding program, the matching procedure yields biased estimates as public support may be potentially endogenous to firm R\&D efforts.

There are other approaches that control for the "selection on unobservables," such as instrumental variables procedures, difference-in-difference regressions or regression discontinuity design. Unfortunately, as we explain in the next sub-section, our available information did not allow us to apply these methodologies.

Given our data restrictions, our estimation strategy consists of two stages. First, we follow a matching procedure to select the control sample. For each period, we estimate a probit model to obtain the propensity scores that allow us to build the counterfactual. Specifically, our first equation is devoted to the participation of firm $i(i=1 \ldots N)$ in the CDTI funding programme during year $t(t=1 \ldots T)$ and is given by: 


$$
y_{i t}=\left\{\begin{array}{l}
1 \text { if } y_{i t}^{*}=\boldsymbol{x}_{\mathbf{1} i t} \boldsymbol{\beta}_{\mathbf{1}}+u_{i t}>0 \quad u_{i} \approx \text { iid } N\left(0, \sigma_{u}^{2}\right) \\
0 \text { otherwise }
\end{array}\right.
$$

where $y_{i t}^{*}$ is a latent dependent variable, $\boldsymbol{x}_{\mathbf{1 i t}}$ is the vector of explanatory variables, $\boldsymbol{\beta}_{\mathbf{1}}$ is the vector of coefficients and $u_{i t}$ is the error term. Firm $i$ will participate if $y_{i t}^{*}$ is positive.

To define the matched samples, we choose the caliper matching algorithm with replacing, in which participants are matched with the non-participants that are closest in terms of the propensity score subject to the constraint that the maximum distance between the treated and non-treated firms can be no greater than $0.005 .^{8}$

However, as we explain in detail in Sect. 5, because of data availability, we cannot be sure about the fulfilment of the conditional independence assumption. Therefore, we do not quantify the stimulus effect of public support by the mean difference in outcome variables of the matched pairs. Instead, in a second step, we estimate an equation for each of our measures of technological inputs and outputs, $g_{i t}$, in the two matched samples:

$$
g_{i t}=\lambda y_{i t}+\boldsymbol{x}_{\mathbf{2 i t}} \boldsymbol{\beta}_{\mathbf{2}}+\varepsilon_{i t}
$$

In this equation, besides the dummy variable that denotes observed participation in CDTI programmes, $y_{i t}$, we include a vector of other potential determinants, $x_{2 i t}$. In every case, we adapt the econometric specification to the continuous or binary character of the dependent variable. Differences in estimated $\lambda$ between the two periods would reflect a heterogeneous impact of CDTI loan programmes between expansion and recession periods. This heterogeneity would be consistent with both a different effectiveness of public loans in adverse economic conditions and with reaction of awarded firms to the changes in the programme design to reduce the failure rate of reimbursements. Coefficient $\lambda$ will capture the net effect of these two.

\subsection{Data and variables}

The database used for the analysis is provided by the CDTI. The CDTI database includes information about Spanish firms' participation in its financing programmes. The specific features of CDTI programmes during the two periods considered in this paper (2002-2005 and 2010-2012) were explained in the previous section.

The information from the CDTI has been complemented with two different control samples of firms not receiving aid. These records were provided by the Spanish Institute of Statistics (INE) on the basis of the annual responses to the Spanish Innovation Survey. ${ }^{9}$ After merging the databases, the sample for the period 2002-2005 includes 13,498 observations and 1764 awarded projects, while in the case of the

\footnotetext{
${ }^{8}$ The procedure is performed in Stata 13 using the psmatch2 routine implemented by Leuven and Sianesi (2003).

${ }^{9}$ The data from the INE are anonymised for quantitative variables, so firms from the control sample cannot be identified. Also for reasons of anonymization, we cannot identify rejected proposals in our database.
} 
Table 2 Definition of variables

Belonging to a group

CDTI participant

Continuous R\&D performer

Export intensity

Exporter

Financial constraints

Fixed capital investment intensity

Foreign capital

Innovation intensity

Innovation performer

Internal R\&D intensity

Internal $R \& D$ performer

Labour productivity

Objective employment

Patent application

Process innovation

Product innovation

Public firm

R\&D performer

R\&D personnel intensity

Sector of activity

Agriculture

Construction

Manufacturing

Services
Dummy variable which takes the value 1 if the firm belongs to a group

Dummy variable which takes the value 1 if the firm participates in a project awarded by the CDTI in the current year

Dummy variable which takes the value 1 if the firm carries out R\&D activities on a constant basis

Ratio of exports over sales in the current year

Dummy variable which takes the value 1 if the company exports during the period

Dummy variable which takes the value 1 if the firm declared that innovation is hindered by financial constraints in the last three years

Ratio of net fixed capital investment per employee in the current year

Dummy variable which takes the value 1 if the firm is partly owned by a foreign firm during the period (more than $50 \%$ of foreign capital)

Ratio of innovation expenditure over total employment in the current year

Dummy variable which takes the value 1 if the firm has positive innovation expenditure during the year

Ratio of internal R\&D expenditure over total employment in the current year

Dummy variable which takes the value 1 if the firm has positive expenditure on internal $R \& D$ during the year

Ratio of sales over total employment in the current year

Dummy variable which takes the value 1 if the firm declared that job creation or job maintenance were relevant objectives of innovation activity in the last three years

Dummy variable which takes the value 1 if the firm applied for patents during the last three years

Dummy variable which takes the value 1 if the firm obtained a process innovation during the last three years

Dummy variable which takes the value 1 if the firm obtained a product innovation during the last three years

Dummy variable which takes the value 1 when the firm is partly publicly owned (more than $50 \%$ of public capital during the period)

Dummy variable which takes the value 1 if the firm has positive expenditure on $R \& D$ during the year

Ratio of R\&D employment over total employment in the current year

Dummy variable which takes the value 1 if the company works in agriculture activities

Dummy variable which takes the value 1 if the company works in construction activity

Dummy variable which takes the value 1 if the company belongs to manufacturing sectors

Dummy variable which takes the value 1 if the company belongs to services sectors 
Table 2 (continued)

SME

Start-up

Technological cooperation

Type of R\&D activity

Applied

Basic

Development
Dummy variable which takes the value 1 if the company has fewer than 250 employees and sales are lower than $€ 40 \mathrm{~m}$ in the current year

Dummy variable which takes the value 1 if the firm was created during the last three years

Dummy variable which takes the value 1 if the company established technological cooperation agreements with other partners during the last three years

Dummy variable which takes the value 1 if the firm has positive expenditure on applied research activities in the current year

Dummy variable which takes the value 1 if the firm has positive expenditure on basic research activities in the current year

Dummy variable which takes the value 1 if the firm has positive expenditure on technological development in the current year

period 2010-2012, the sample includes 29,921 observations and 920 awarded projects.

As we have mentioned before, the use of matching procedures is conditioned by the availability of information. In particular, one constraint for our analysis is that we cannot merge the information of both periods, as the empirical analysis for the second period was undertaken at secure places in the INE. In addition, the set of variables provided by the INE about non-supported firms differs between the two periods analysed in the paper, as each of the control samples was available at different moments and under distinct confidentiality conditions. The list and definitions of all variables used in the study are shown in Table 2.

In Table 3, the means of the main variables for participants and non-participants, distinguishing between both periods, are shown.

Specifically, we use information about four technological inputs and three technological outputs. As for the inputs, we consider the intensity of internal R\&D expenditures, innovation expenditures, $R \& D$ personnel and fixed capital investment. In all cases, the variables are defined as ratios over total employment.

As can be seen in Table 3, and regardless of the period considered, the means of these variables are greater in firms supported by CDTI programmes than in firms without public aid, although in the case of fixed capital intensity the difference of means is not statistically significant. Comparing both periods, internal R\&D and innovation intensities decreased in the second period not only for non-supported firms but also for firms financed by the CDTI. However, it is interesting to highlight that, during the crisis, the percentage of non-supported firms which perform R\&D activities sharply decreased, but the percentage of firms supported by the CDTI slightly increased. A similar pattern is found in the case of R\&D personnel intensity.

Regarding technological outputs, we have information about the generation of process and product innovations and the application for patents. Again, the sample mean of these variables is higher for participants in CDTI programmes than for non-participants. In addition, during the crisis, a smaller percentage 


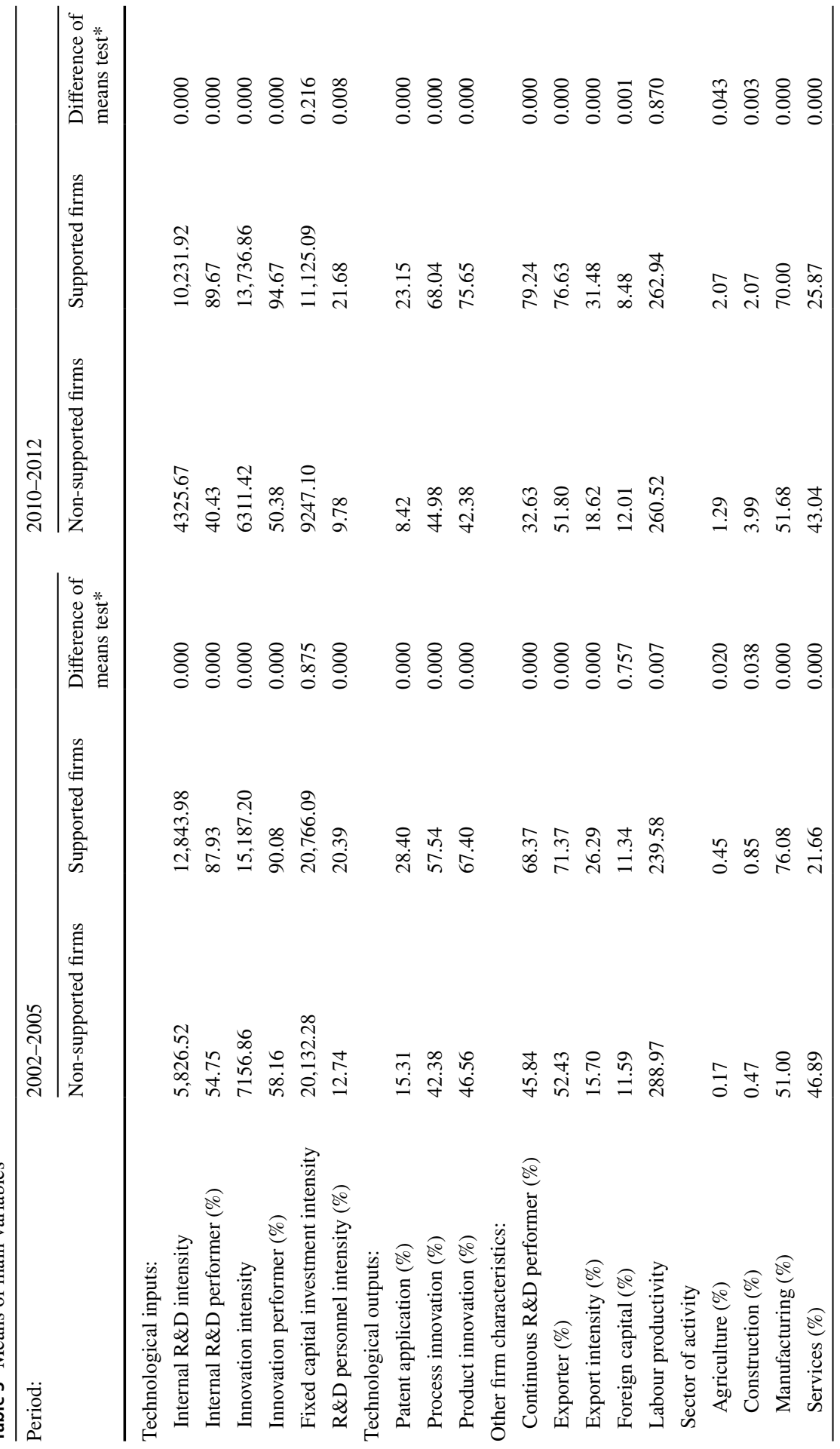




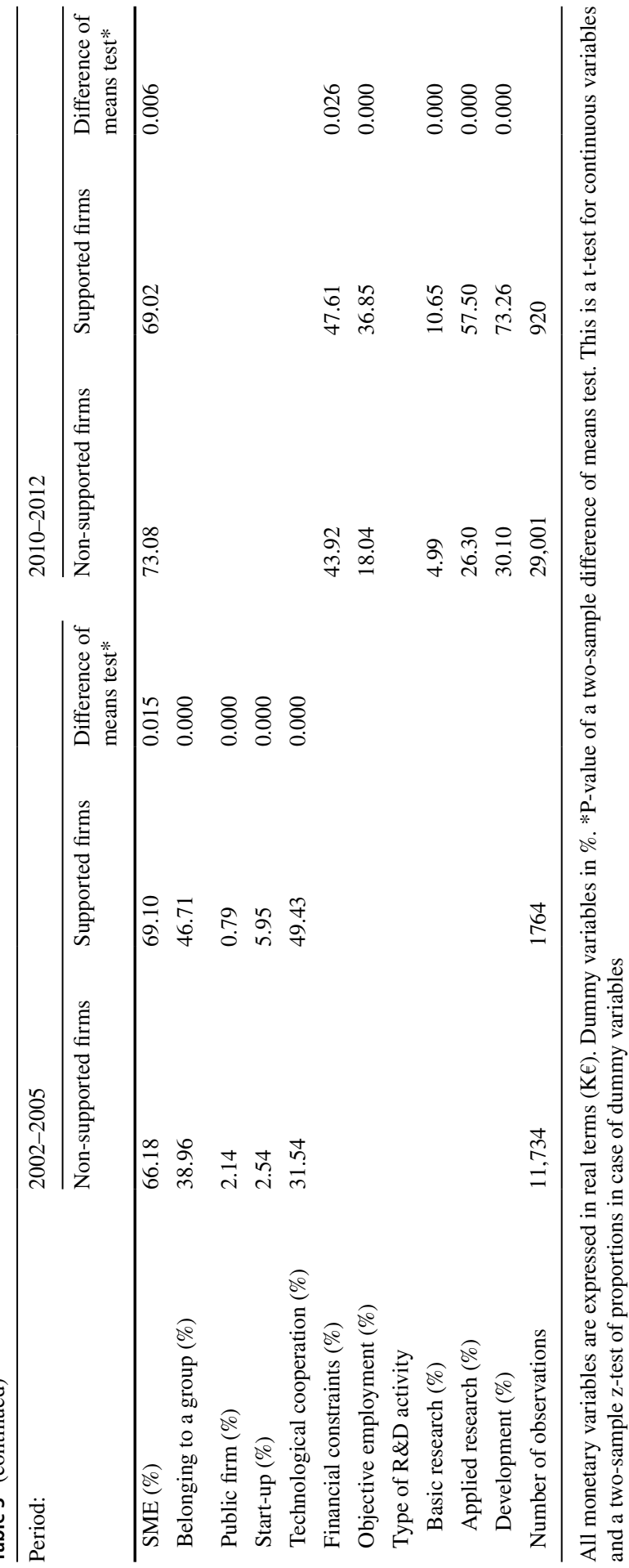


of (supported and non-supported) firms applied for patents. However, and as in the case of technological inputs, for firms supported by the CDTI, the chance of obtaining process and product innovations increased.

The selection of explanatory variables in Eq. (1) is based on previous empirical literature (Czarnitzki and Licht 2006; Czarnitzki and Lopes-Bento 2014; García and Mohnen 2010; Huergo and Moreno 2017) and is also determined by the availability of information in our databases. Unfortunately, as we have explained before, although we have several common variables, we cannot use exactly the same set of information for both periods. The set of common variables includes being a continuous $R \& D$ performer, export intensity, receiving foreign capital investment, labour productivity, activity sector (agriculture, manufacturing, services or construction) and being a small or medium-sized enterprise (SME).

Most previous papers consider measures of the firm's technological profile as explanatory variables of its participation in public aid programmes. In general, it is expected that the probability of applying for public funding increases when the propensity to perform R\&D projects is higher. Therefore, to indicate that the firm is a continuous $R \& D$ performer, we use a dummy variable that takes the value 1 if the firm carries out $\mathrm{R} \& \mathrm{D}$ activities on a constant basis.

Another aspect that should be taken into account is the firm's international competitive position, which we are going to approach by the exporting activity. As Czarnitzki and Licht (2006) point out, operating in international markets might reflect the ability of exporters to transform innovations into successful products. In addition, as they are more experienced in dealing with bureaucracy compared to non-exporters, they might also be facing lower application costs (Takalo et al. 2013). In our samples, the presence of continuous R\&D performers and exporters is higher among supported firms. Moreover, this presence was bigger during the crisis than it was before the crisis.

Labour productivity is another indirect measure of a firm's competitive position. Table 3 shows that this variable is smaller for supported firms before the crisis. However, there are no differences between funded and non-funded firms during the crisis. Comparing both periods, we find that labour productivity of participants increases in the second sample.

The presence of foreign capital among shareholders is used as an indicator of the ease of access to external capital markets. There are no significant differences between funded and non-funded firms before the crisis. However, the percentage of supported firms with more than $50 \%$ of foreign capital sharply decreased during the crisis and is smaller for participants in CDTI programmes.

We also consider the firm's size in our specifications. The expected effect of this variable on participation in public programmes is ambiguous. The benefits of public aid for SMEs might be higher because they are more affected by innovation-related market failures. However, large firms typically have more resources with which to undertake R\&D projects and apply for financial support. The statistics in Table 3 show that firms funded by the CDTI are smaller than nonsupported companies in terms of employment. The crisis reduced the mean size of both supported and non-supported firms. However, the percentage of SMEs 
(firms with fewer than 250 employees and with sales of less than $€ 40 \mathrm{~m}$ ) with CDTI support was slightly larger/smaller before/during the crisis.

The statistics in Table 3 also show that the percentage of supported firms operating in the manufacturing sector is larger than the percentage of non-supported firms. The opposite happens for firms operating in the services sector. Although the result is similar in both periods, the percentage of supported firms in the services and construction sectors slightly increased during the crisis.

Besides these common variables, we have information about business group membership, the presence of public capital, being a start-up and having technological agreements only for the period 2002-2005. Although belonging to a group and the presence of public capital can be indicators of the ease of access to external capital markets, they possibly also imply a better knowledge of the public aid system. The expected effect of being a start-up is not clear. Although older firms are more likely to use public aid, young firms tend to be more financially constrained and, consequently, they might apply for and receive public aid more regularly. Finally, firms that adopt technological cooperation as strategy invest more in R\&D when these practices are complementary (Cassiman and Veugelers 2002), and in this case, we would expect a higher probability of applying for public aid. Notice that, with the exception of public capital, the means of these variables are higher among supported firms during this period.

On the other hand, we have data about the existence of financial constraints that hinder a firm's innovation and about the relevant objective of its innovation only for the period 2010-2012. Firms with liquidity constraints are expected to have more difficulties undertaking R\&D projects and might apply for public aid more frequently. However, note that CDTI programmes consist mainly of loans that firms must reimburse under favourable conditions. In this sense, applicants should have an acceptable solvency situation in order to reduce the default ratio. The existence of financial constraints can reduce the chance of being funded by the public agency. In our sample, the percentage of firms which face financial constraints for innovation between 2010 and 2012 is larger among supported firms. Similarly, the percentage of firms which declare that job creation (or job maintenance) is a relevant objective of its innovation activity is also larger for this group of firms.

Finally, time dummy variables are included in all estimates to allow for business cycle effects and changes in the CDTI budget. In fact, direct funding provided by the CDTI between 2010 and 2012 decreased around 50\%.

As we have mentioned before, once we have defined matched samples for both periods, in a second step we estimate different equations for each of our measures of technological inputs and outputs to quantify the stimulus effect of public support. In these estimates, besides the dummy variable that denotes participation in CDTI programmes, we include the same explanatory variables as in Eq. (1), with two remarkable exceptions. Firstly, only for the period 2010-2012, we take into account the type of $R \& D$ activity undertaken by the firm: applied research, basic research or technological development. ${ }^{10}$ Secondly, internal R\&D intensity is also

10 This information is not available for the period 2002-2005. 
added as an explanatory variable in technological output equations. This allows us to discuss the existence of direct and indirect effects of public funding on technological performance.

\section{Results}

In this section, we analyse the results of estimating the impact of participation in CDTI programmes through the economic cycle on some performance measures of Spanish firms. As we explained in the previous section, we compare the impact of CDTI programmes for two different periods: 2002-2005, which are years of expansion, and 2010-2012, which fully correspond to the economic crisis in Spain.

We start by using a matching procedure to construct a sample of firms that do not participate in CDTI programmes but have characteristics similar to funded firms prior to participation. The implementation of this procedure is conditioned by the availability of information in our database. In particular, one constraint for our analysis is that we cannot merge the information of both periods, as the empirical analysis for the second period was undertaken at secure places in the INE. This also prevents us from including lagged values of innovation outputs in the estimation of Eq. (1). Notice that, as is usual in Community Innovation Surveys, our dummies for patent application, product innovation and process innovation refer to a three-year period (see definitions in Table 2). For instance, the dummy for product innovation in the year 2012 takes the value 1 if the firm obtained a product innovation in the period 2010-2012. Therefore, to avoid endogeneity concerns, the lag for this variable to be included as an explanatory variable of the probability of participation in CDTI programmes should refer to the year 2009, which is not possible because the time span in the second period is too short (2010-2012).

This limitation raises concerns about the fulfilment of the conditional independence assumption in the matching procedure. For this reason, for each outcome variable, we do not estimate the average treatment effect by the mean difference in the variable of the matched pairs. Instead, in a second stage, we undertake an additional estimation in matched samples for each outcome measure. In these estimates, as explanatory variables, we include the dummy for participation in CDTI programmes and a set of control variables related to the technological profiles of firms (especially, but not only, the variable "continuous R\&D performer").

Firstly, we present the estimates of the equation for the probability of participation in CDTI programmes. In a second stage, we analyse the impact of this participation on some measures of technological inputs and outputs in matched samples.

\subsection{The probability of participation in CDTI programmes}

To compute the predicted probability of participating in CDTI programmes (propensity score) before and during the crisis, we estimate a probit model for every period. As we have explained, the type of information provided by the INE about non-supported firms differs between the two periods analysed in the paper. As a 
Table 4 Participation within CDTI projects (probability of participation)

\begin{tabular}{|c|c|c|c|c|}
\hline Period & $\begin{array}{l}2002-2005 \\
\text { (1) }\end{array}$ & & $\begin{array}{l}2010-2012 \\
\text { (2) }\end{array}$ & \\
\hline Continuous R\&D performer & $0.055^{* * *} *$ & $(0.006)$ & $0.047 * * *$ & $(0.002)$ \\
\hline Export intensity & $0.069 * * *$ & $(0.010)$ & $0.011 * * *$ & $(0.000)$ \\
\hline Foreign capital & $-0.029 * * *$ & $(0.008)$ & $-0.011 * * *$ & $(0.001)$ \\
\hline Labour productivity & $0.020^{*}$ & $(0.012)$ & $0.007 * *$ & $(0.002)$ \\
\hline SME & $0.026 * * *$ & $(0.006)$ & $-0.005^{* *}$ & $(0.002)$ \\
\hline \multicolumn{5}{|l|}{ Sector of activity } \\
\hline Construction & $0.091 *$ & $(0.057)$ & $-0.012 * *$ & $(0.003)$ \\
\hline Manufacturing & $0.040^{*}$ & $(0.021)$ & -0.007 & $(0.005)$ \\
\hline Services & $-0.053 * *$ & $(0.021)$ & $-0.016^{* *}$ & $(0.005)$ \\
\hline \multicolumn{5}{|l|}{ Time dummies } \\
\hline 2003 & 0.003 & $(0.008)$ & & \\
\hline 2004 & $0.033 * * *$ & $(0.009)$ & & \\
\hline 2005 & $0.025 * * *$ & $(0.008)$ & & \\
\hline 2011 & & & $-0.005^{* *}$ & $(0.001)$ \\
\hline 2012 & & & $-0.017 * * *$ & $(0.001)$ \\
\hline Belonging to a group & $0.031 * * *$ & $(0.006)$ & & \\
\hline Public firm & -0.033 & $(0.021)$ & & \\
\hline Start-up & $0.169 * * *$ & $(0.024)$ & & \\
\hline Technological cooperation & $0.043 * * *$ & $(0.006)$ & & \\
\hline Financial Constraints & & & 0.000 & $(0.000)$ \\
\hline Objective employment & & & $0.006^{* * *}$ & $(0.002)$ \\
\hline Log of likelihood function & -4785.8 & & -3561.4 & \\
\hline Number of observations (censored) & $13,486(1587)$ & & $29,921(920)$ & \\
\hline
\end{tabular}

Marginal effects $(d y / d x)$ are computed at sample means. For dummy variables, the marginal effect corresponds to change from 0 to 1 . Estimated standard errors are in parentheses. Coefficients significant at $1 \% * * *, 5 \% * *, 10 \% *$. The estimate includes the constant. Time dummy excluded for the year 2002 in column (1) and for the year 2010 in column (2)

consequence, we have also considered different specifications for probit models of CDTI programmes, although we have used the maximum set of available common variables. As can be seen in Table 4, most explanatory variables are statistically significant and marginal effects of common variables have the same sign in both estimates.

Regardless of the period, continuous R\&D performers-firms that carry out R\&D activities on a constant basis - achieve a higher probability of participating in CDTI programmes than other firms. Applicants that show previous R\&D experience seem to prepare more solid proposals because of their knowledge capital and are expected to have a lower probability of project failure. This result is in accordance with Czarnitzki and Hussinger (2004), Huergo et al. (2016) and Huergo and Moreno (2017), who also obtain that firms with a higher 
technological profile present a bigger probability of participation in public aid programmes. The impact of this variable is quite similar before and during the crisis. ${ }^{11}$

With respect to the other common explanatory variables, being an exporter increases the probability of participating in these public programmes. This might explain why the innovative activity of firms with international experience suffered less from the recessive effect of the crisis. The presence of foreign capital has a negative effect on the probability of participating in CDTI programmes in both periods. This result, in accordance with Huergo and Moreno (2017), suggests that public agencies are less prone to finance firms that belong to foreign groups than domestic firms, probably because the latter tend to apply for public aid more frequently. More productive firms in terms of labour productivity are also more likely to participate in CDTI programmes. More productive firms are more capable of assimilating new knowledge, whether it is developed internally or externally, and the probability of success increases. Again, the explanatory power of the last two variables is bigger before the crisis.

Interestingly, firm size had different effects before and during the crisis. Although SMEs are usually more influenced by innovation-related market failures and their benefits from public aid might consequently be higher, large firms usually have more resources with which to undertake $R \& D$ projects and apply for the aid. SMEs were more likely to participate in CDTI programmes before the crisis. However, and in accordance with Huergo et al. (2016), the probability of participating during the recession was smaller for SMEs. This result suggests that applying for CDTI loans has some costs (time and searching for information) that might be bigger during a crisis, so larger firms will have a higher probability of participation. Moreover, this result is consistent with the evolution of the number of innovative SMEs in Spain. Between 2009 and 2012, this figure diminished around 20\%, whereas the decrease was 6\% for big companies (INE 2009-2012). The effect of expanded requirements on real guarantees by the CDTI during this period should also be considered. These guarantees are more difficult for small firms to provide.

In the same line, Aristei et al. (2017) find that the percentage of subsidised firms in Spain and France during the period 2007-2009 was higher among large companies. As an explanation for this result, they point to the complex administrative procedures to access R\&D grants, which only firms with larger resources can easily handle. Despite this evidence, in the case of firms supported by the CDTI, SMEs do not seem to have been punished by these administrative barriers during the first period, probably because CDTI procedures were more adapted to SMEs' needs.

As for the rest of the variables, before the crisis, being a start-up positively increased the probability of participating in the soft loan programme. Although older firms are more likely to know and use public aid programmes, younger firms are usually more financially constrained, having more incentives to apply for and receive them. In addition, having technological agreements in general

\footnotetext{
11 As we use a different database for each period and these two databases cannot be merged, it is not possible to test whether estimated impacts in both periods are statistically equal.
} 
increases the probability of participating in CDTI programmes. Group membership also positively affects the chance of participation. Unfortunately, we do not have information about these variables for CDTI programmes during the economic recession.

In addition, during the crisis, it seems that the CDTI supported firms which use innovative activity to create or maintain jobs. This fact can be associated with the big job losses suffered by the Spanish economy during this long financial crisis. Surprisingly, being hindered by financial constraints to innovate does not seem to affect the probability of participating in the CDTI programme. This evidence is coherent with the features of CDTI aid, which consists of loans that firms must reimburse under favourable conditions. In order to reduce the default ratio, applicants should have an acceptable solvency situation. Our result is also in consonance with Busom and Vélez-Ospina (2020), who obtain that firms with difficulties accessing external funding are more likely to participate in subsidy programmes during the expansion, but not during the recession. They argue that this result can be explained by a break in firms' innovation plans during the crisis, so support is not requested. Unfortunately, our indicator of financial constraints is not available in our database for the period prior to the crisis.

Regarding the sectorial dimension, it seems that CDTI programmes are more adapted to manufacturing sectors, although, after the crisis, this variable lost its significance, reflecting the adverse conditions faced by this activity branch. Firms operating in services reduced the probability of participation in both periods. On the other hand, construction, one of the sectors most punished by the crisis, also seems to have lost its favourable position.

As for time dummies, marginal effects show a positive trend in the first period and a negative path during the crisis. This result can be explained by the increased budget restrictions in CDTI public funding during the second period as a result of the crisis.

The estimates in Table 4 allow us to compute the propensity score needed to define matched samples. As we have already mentioned, we use the caliper matching algorithm with replacing, in which participants are matched with the non-participants that are closest in terms of the propensity score subject to a maximum threshold distance. Before the matching, in the sample there are 1764 and 920 observations that correspond to the observations of supported firms in the periods 2002-2005 and 2010-2012, respectively. The treated group consists of 1587 and 920 observations of supported firms in each period. The supported firms are matched respectively with the control group: 1,509 and 858 observations of non-participants in CDTI programmes.

In order to assess the matching quality, we check whether the distribution of covariates is balanced in the treated and control groups (Table 5). Notice that, after matching, all variables have the same mean in both groups.

In addition, to check whether the distribution of covariates is balanced in the treated and control groups, Table 6 reports that, for all covariates, the mean and median absolute biases are also reduced. Regardless of the period, the Pseudo-R2 after matching is close to zero, which suggests that after matching, the covariates do not explain the probability of participation well. Overall, it seems that the matching 
Table 5 Balancing tests: difference of means

\begin{tabular}{|c|c|c|c|c|c|c|}
\hline & \multicolumn{2}{|l|}{ Mean } & \multirow[b]{2}{*}{$\%$ bias } & \multirow[b]{2}{*}{ Reduction } & \multicolumn{2}{|l|}{ t-test } \\
\hline & Treated & Control & & & $\mathrm{t}$-value & p-value \\
\hline \multicolumn{7}{|l|}{ Panel A: 2002-2005 } \\
\hline Continuous $\mathrm{R} \& \mathrm{D}$ performer & 0.684 & 0.709 & -5.2 & 88.9 & -1.61 & 0.107 \\
\hline Export intensity & 0.263 & 0.252 & 4.0 & 89.5 & 1.11 & 0.265 \\
\hline Foreign capital & 0.113 & 0.112 & 0.4 & 59.5 & 0.11 & 0.915 \\
\hline Labour productivity & 0.194 & 0.200 & -2.8 & 60.5 & -0.83 & 0.406 \\
\hline SME & 0.690 & 0.699 & -1.8 & 69.7 & -0.55 & 0.583 \\
\hline \multicolumn{7}{|l|}{ Sector of activity } \\
\hline Construction & 0.009 & 0.010 & -2.1 & 55.6 & -0.52 & 0.600 \\
\hline Manufacturing & 0.762 & 0.765 & -0.5 & 99.1 & -0.16 & 0.874 \\
\hline Services & 0.215 & 0.211 & 0.9 & 98.4 & 0.29 & 0.773 \\
\hline \multicolumn{7}{|l|}{ Time dummies } \\
\hline 2003 & 0.209 & 0.206 & 0.7 & 66.3 & 0.21 & 0.835 \\
\hline 2004 & 0.290 & 0.284 & 1.3 & 84.3 & 0.37 & 0.709 \\
\hline 2005 & 0.308 & 0.305 & 0.7 & 57.3 & 0.22 & 0.826 \\
\hline Belonging to a group & 0.468 & 0.457 & 2.2 & 86.2 & 0.64 & 0.521 \\
\hline Public firm & 0.008 & 0.005 & 2.4 & 78.8 & 1.05 & 0.296 \\
\hline Start-up & 0.057 & 0.051 & 3.1 & 81.3 & 0.82 & 0.413 \\
\hline Technological cooperation & 0.495 & 0.491 & 0.8 & 97.8 & 0.24 & 0.813 \\
\hline Number of observations & 1,587 & 1,509 & & & & \\
\hline \multicolumn{7}{|l|}{ Panel B: 2010-2012 } \\
\hline Continuous R\&D performer & 0.792 & 0.795 & -0.5 & 99.5 & -0.12 & 0.908 \\
\hline Export intensity & 0.315 & 0.323 & -2.8 & 93.3 & -0.57 & 0.572 \\
\hline Foreign capital & 0.085 & 0.087 & -0.7 & 93.8 & -0.18 & 0.868 \\
\hline Labour productivity & 0.210 & 0.199 & 5.1 & 68.2 & 1.10 & 0.270 \\
\hline SME & 0.690 & 0.715 & -5.5 & 39.0 & -1.17 & 0.241 \\
\hline \multicolumn{7}{|l|}{ Sector of activity } \\
\hline Construction & 0.021 & 0.026 & -3.2 & 71.9 & -0.77 & 0.441 \\
\hline Manufacturing & 0.700 & 0.693 & 1.4 & 96.5 & 0.30 & 0.761 \\
\hline Services & 0.259 & 0.260 & -0.2 & 99.4 & -0.05 & 0.958 \\
\hline \multicolumn{7}{|l|}{ Time dummies } \\
\hline 2011 & 0.360 & 0.355 & 0.9 & 84.3 & 0.19 & 0.864 \\
\hline 2012 & 0.165 & 0.154 & 2.6 & 93.2 & 0.64 & 0.525 \\
\hline Financial constraints & 0.476 & 0.485 & -1.7 & 76.4 & -0.37 & 0.709 \\
\hline Objective employment & 0.368 & 0.349 & 4.5 & 89.6 & 0.87 & 0.382 \\
\hline Number of observations & 920 & 858 & & & & \\
\hline
\end{tabular}

The econometric model used for the matching procedure is based on the estimates of Table 4 
Table 6 Overall measures of covariate balancing

\begin{tabular}{|c|c|c|c|c|c|c|c|}
\hline & \multirow{2}{*}{$\begin{array}{l}\text { Mean } \\
\text { abs std. } \\
\text { bias }\end{array}$} & \multirow{2}{*}{$\begin{array}{l}\% \text { mean } \\
\text { bias reduc- } \\
\text { tion }\end{array}$} & \multirow{2}{*}{$\begin{array}{l}\text { Median } \\
\text { abs std. } \\
\text { bias }\end{array}$} & \multirow{2}{*}{$\begin{array}{l}\% \text { Median } \\
\text { bias reduc- } \\
\text { tion }\end{array}$} & \multirow[t]{2}{*}{ Pseudo $\mathrm{R}^{2}$} & \multicolumn{2}{|l|}{ LR-test $^{\mathrm{a}}$} \\
\hline & & & & & & $\overline{\mathrm{Chi}^{2}}$ & $\mathrm{p}>\mathrm{Chi}^{2}$ \\
\hline \multicolumn{8}{|c|}{ Panel A: 2002-2005 } \\
\hline Before matching & 20.4 & & 11.2 & & 0.084 & 872.14 & 0.000 \\
\hline After matching & 1.9 & $90.7 \%$ & 1.8 & $83.9 \%$ & 0.002 & 10.18 & 0.809 \\
\hline \multicolumn{8}{|c|}{ Panel B: 2010-2012 } \\
\hline Before matching & 30.5 & & 26.4 & & 0.133 & 1095.39 & 0.000 \\
\hline After matching & 2.4 & $92.1 \%$ & 2.2 & $91.7 \%$ & 0.002 & 5.19 & 0.951 \\
\hline
\end{tabular}

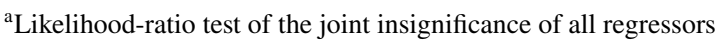

procedure has been able to balance the treated and non-treated groups, creating a homogenous group with common characteristics before participation.

\subsection{Impact of public support on technological inputs and outputs}

Table 7 shows the results of the estimates of the equations for the determinants of technological inputs in the two matched samples that we have obtained for the two periods analysed. To deal with potential endogeneity problems, most explanatory variables are introduced in all equations with one lag.

We consider four different technological inputs: internal R\&D intensity (columns (1) to (4)), innovation intensity (columns (5) and (6)), R\&D personnel intensity (columns (7) and (8)) and fixed capital intensity (columns (9) and (10)). In the case of internal R\&D intensity, we present the results of a Generalized Tobit model where participation and intensity equations are jointly estimated by maximum likelihood. Notice that the correlation term rho between the two equations is non-significant in both periods (previous to and during the crisis), which suggests that it is not necessary to estimate a selection model for the observed intensity. However, we prefer to present these selection models in order to distinguish the impact of CDTI programmes on both, the probability of undertaking technological activities and their intensity. We also estimate a Generalized Tobit model for total innovation expenditures (which include internal and external R\&D), although in this case, we only present the results for the intensity equation.

As can be seen in the first row of Table 7, participation in CDTI programmes positively affected all our measures of technological inputs both before and during the crisis. As we explained before, the effect of the financial crisis on the impact of public aid on technological input is ambiguous. Subsidies or loans might be more effective in crisis years because firms face more financial constraints, so public aid is needed more to undertake $R \& D$ activities than in expansion years. However, a smaller impact is expected during recessions if firms use public funds to reduce 


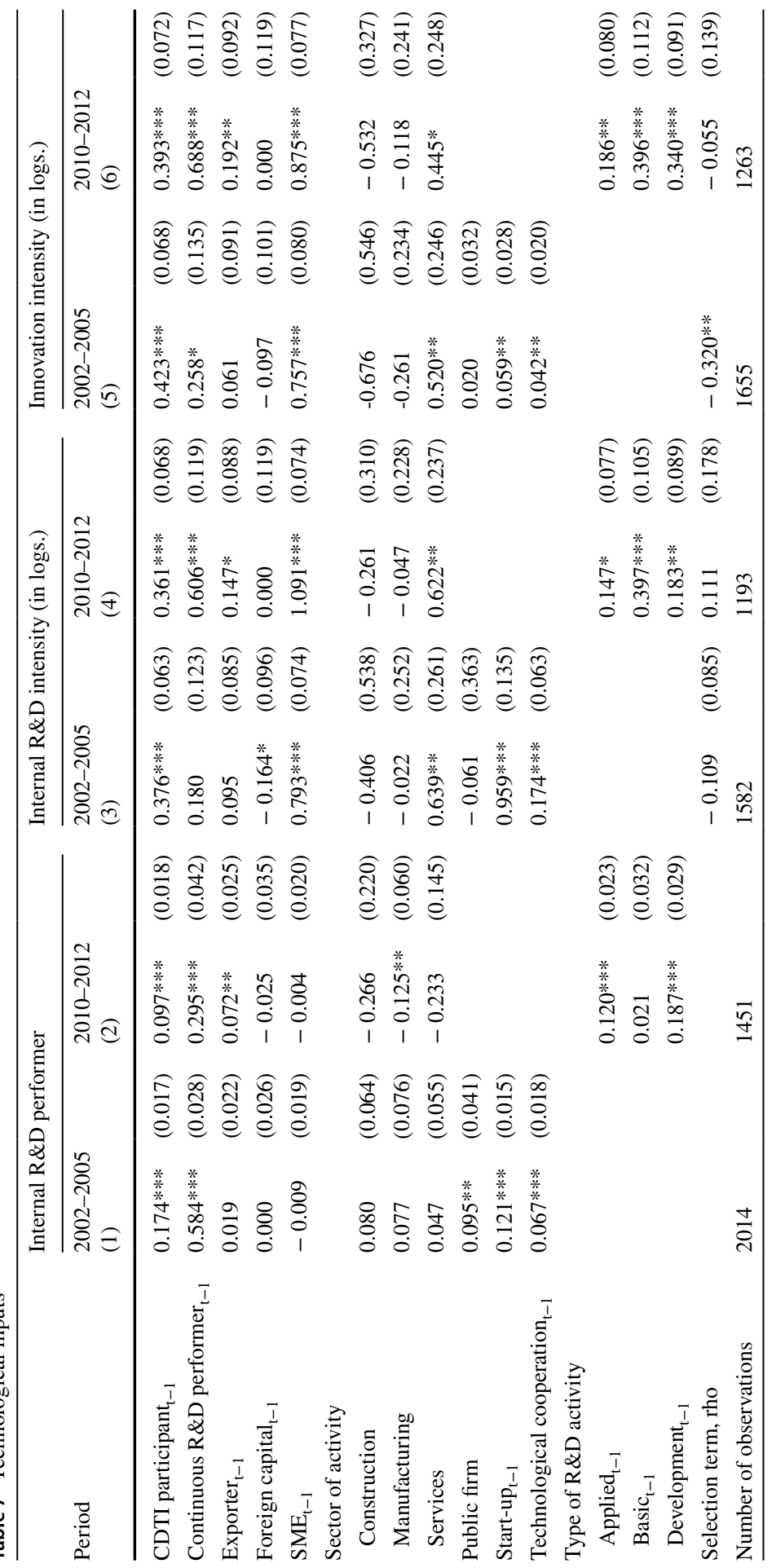




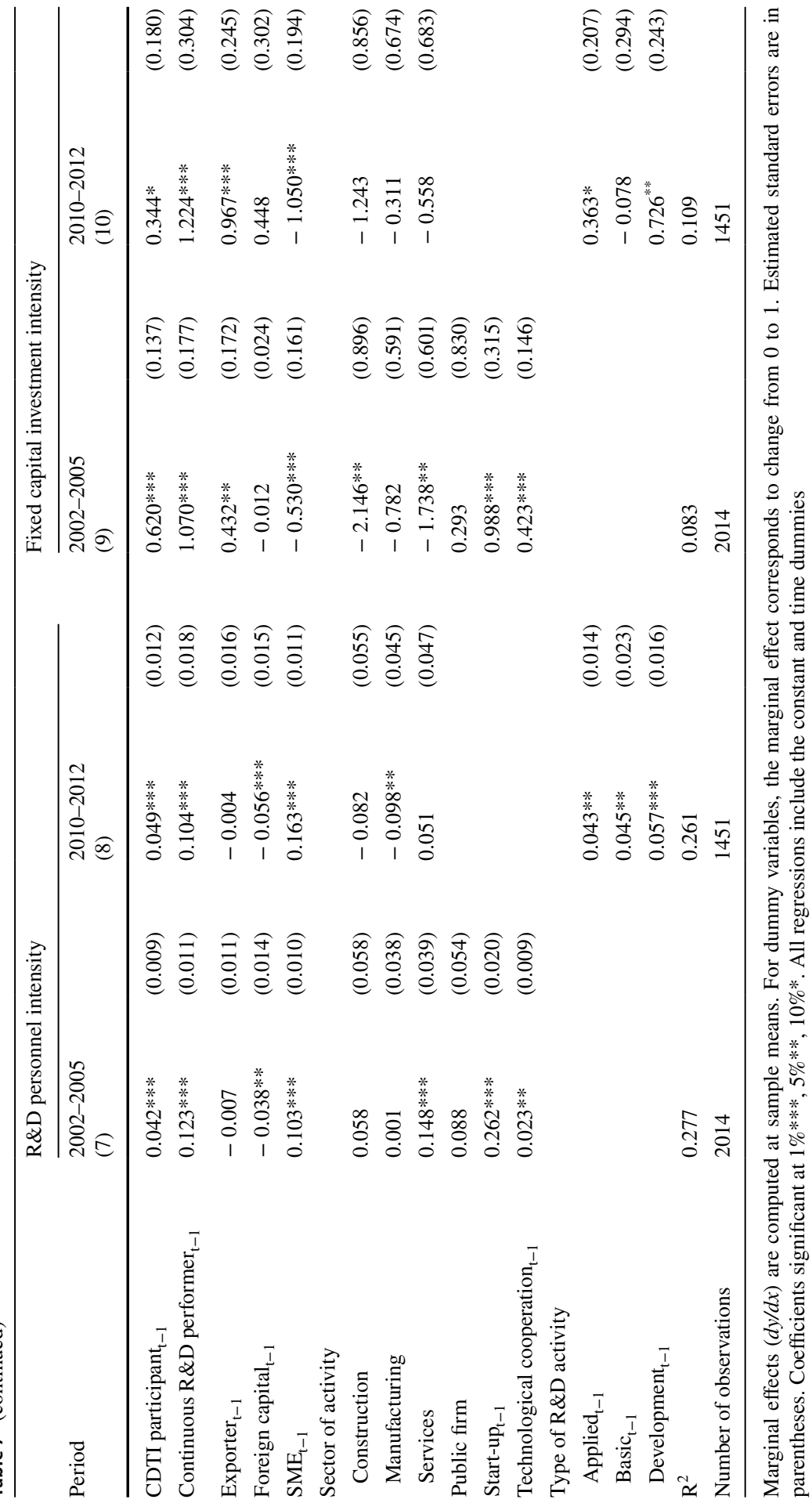


private investments that they would have made in non-crisis years (Hud \& Hussinger, 2015).

With respect to the decision to engage in internal $R \& D$ activities, the estimations in columns (1) and (3) of Table 7 show that being awarded a CDTI loan increases the probability of conducting R\&D activities with one's own resources. Participation in CDTI programmes before the crisis increased the probability of self-financing internal $\mathrm{R} \& \mathrm{D}$ activities 17.4 percentage points. The impact was smaller during the economic crisis but still quite relevant: 9.7 percentage points.

As for the intensity of R\&D inputs, once the firm has decided to invest in $R \& D$, public aid also stimulates the intensity of R\&D investment (columns (2) and (4) of Table 7). CDTI public aid remained useful to help firms to undertake R\&D activities during the crisis. In addition, the impact on internal R\&D intensity was quite similar to the one before the crisis.

When we consider innovation intensity, previous results are confirmed. The impact of participating in CDTI programmes is positive and there are no remarkable differences in marginal effects between the two periods. Therefore, the results provide evidence against the hypothesis that R\&D loans (subsidies) fully crowd out private funds for research. However, given that we have no information about the quantity of the loan (or grant), we cannot test the additionality hypothesis.

Table 7 also shows the estimates of the equations for the determinants of R\&D personnel intensity and fixed capital intensity. Given that both variables are expressed in logarithms, the coefficients reported are elasticities or semi-elasticities. Participation in CDTI programmes increased the ratio of R\&D personnel intensity by more than $4 \%$ both before and during the crisis, which points out the relevance of public financing in maintaining R\&D human capital. Busom and Vélez-Ospina (2020) find that the impact of direct support is counter-cyclical in terms of the human resources allocated to $\mathrm{R} \& \mathrm{D}$, measured by the employee-time allocation to innovation activities. They argue that the support has allowed firms to allocate more of their employees' time to R\&D activities, preventing a decline of knowledge capital during the recession.

CDTI public aid also stimulates the intensity of fixed capital investment. However, in this case the impact was bigger, almost double, before the crisis. This result is consistent with a normative change in CDTI programmes in 2008. As of this year, following the European regulations on state aid, CDTI funding only covers the amortisation of physical assets related to the project and not their total purchase price. ${ }^{12}$ However, the impact of public aid was still quite relevant during the crisis, $34.4 \%$. In a period with a strong decrease of fixed capital investment in most Spanish firms, this result again confirms the importance of public support.

Table 7 also shows that, during the crisis, being an exporter not only increased the probability of carrying out R\&D activities but also positively affected R\&D intensity. Specifically, firms operating in international markets are 7.2 percentage points more likely to self-finance internal $R \& D$ activities, stressing the complementarity between internationalisation and R\&D investment strategies. However, before

12 See footnote 6 . 
the crisis, being an exporter did not seem to affect R\&D activities. Nevertheless, in that period, exporting status was highly correlated with the status of continuous $\mathrm{R} \& \mathrm{D}$ performer, and this last variable increases the propensity to undertake internal R\&D by about 58 percentage points.

Unexpectedly, regardless of the period, the probability of undertaking R\&D activities is not affected by firms' size. However, once the firm has decided to invest in $\mathrm{R} \& \mathrm{D}$, SMEs present bigger $\mathrm{R} \& \mathrm{D}$ intensities than large firms. The impact on R\&D intensity was higher during the crisis. This result is consistent with the evolution of innovative firms in the last period: the survival ratio among innovative SMEs as consequence of the crisis was lower than for the rest; it seems that small and medium-sized survivors were those with higher R\&D intensities.

The estimates in Table 7 also allow us to analyse how the type of R\&D activity is related to R\&D intensity in the period 2010-2012. Most firms are focused on applied research and technological development. These kinds of activities are less risky than basic research and allow firms to better face the crisis. Nevertheless, and as expected, firms which spend on basic research activities show the highest R\&D intensities. Unfortunately, we cannot compare this result for the period before the crisis because these variables are absent in our database for the years 2002-2005.

As for the rest of the explanatory variables in Table 7, regardless of the period, continuous $R \& D$ performers present higher R\&D personnel and fixed capital intensities. The presence of foreign capital had a negative effect on R\&D personnel intensity, bigger during the crisis. This result suggests that in the case of subsidiaries, the main $R \& D$ department may be located at the parent company, and this trend might have been even higher during the crisis. In addition, SMEs showed larger R\&D personnel intensities. However, fixed capital investment was smaller for SMEs, especially during the crisis.

In the period 2002-2005, being a start-up and having technological agreements increased both technological inputs. In addition, in the period 2010-2012, firms focused on applied research activities and especially technological development presented a higher fixed capital investment per employee. R\&D personnel intensity was positively affected by $R \& D$ activities regardless of the type, although the biggest coefficient corresponds to technological development.

Table 8 shows the results of the estimates for three alternative measures of innovation outputs: process innovation, product innovation and patent application. Given the binary character of our innovation outputs, the specifications are estimated as probit models. As in Table 7, to deal with potential endogeneity, most explanatory variables are included lagged one period. In these estimates, we consider internal R\&D intensity an explanatory variable, assuming that the more firms spend on R\&D activities, the higher their probability of obtaining technological outputs will be. Notice that, under this assumption, public support can also affect innovation outputs indirectly by increasing R\&D intensity (see Table 7).

As can be seen in Table 8, being supported by the CDTI clearly increased the probability of applying for patents: 6.7 and 3.4 percentage points before and during the crisis, respectively. However, the effect on process and product innovations differed according to the period considered. Participation in CDTI programmes during the crisis increased the probability of achieving product innovations 4.5 percentage 


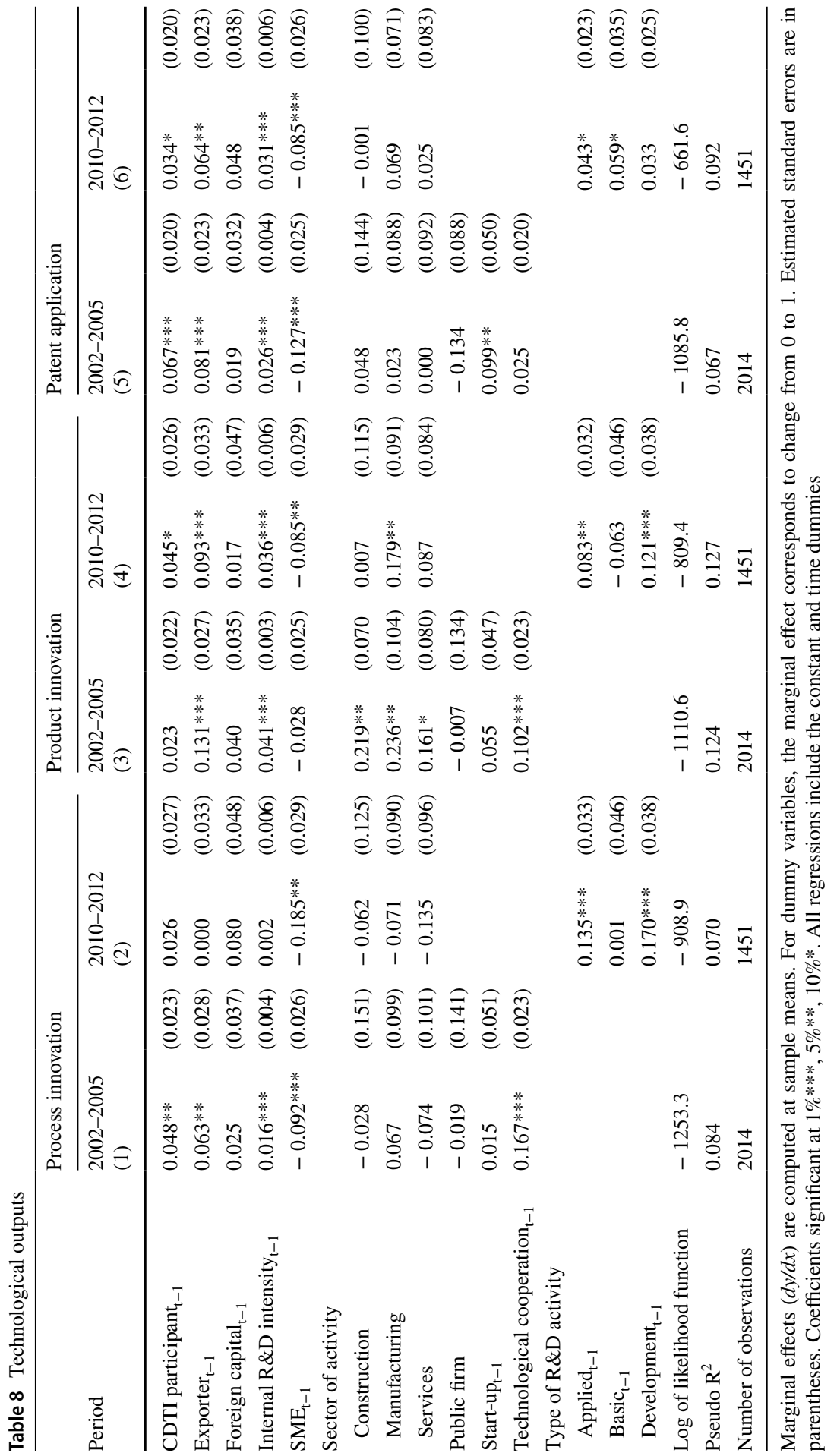


points. However, being supported by CDTI aid did not directly affect the probability of obtaining process innovations in this period. The opposite result is found when we consider the period 2002-2005. Participation in the CDTI programmes increased the probability of achieving process innovations 4.8 percentage points, but did not directly affect the chance of obtaining product innovations. As the purchase of physical assets is usually more relevant for process innovations, this result could be partially explained by the normative change in CDTI funding conditions during the crisis. Given that CDTI funding did not cover the purchase of physical assets as of 2008, firms would have focused more on obtaining product innovations.

However, with the only exception of process innovations in the second period, internal $R \& D$ intensity had a positive impact on the generation of all technological outputs. In this sense, there is an additional indirect effect of the CDTI support on technological results by stimulating internal R\&D intensity.

Regarding other control variables, being an exporter increased the probability of obtaining every technological output, again with the exception of process innovations in the period 2010-2012. However, foreign capital investment did not seem to have any effect. With respect to size, and regardless of the period considered, large firms showed higher propensities to achieve innovation results.

\section{Conclusions}

Nowadays, most governments recognise the relevance of new knowledge as a basic determinant for the growth of countries. In fact, the most important consequence of the well-known Lisbon Treaty (European Council 2002) was an increase in public budgets to support R\&D projects by several European countries during the first years of the 2000s. However, this tendency was interrupted because of the economic crisis and the increase in public budget deficits. As a consequence, many governments introduced austerity measures in the form of spending cuts during this period.

In this context, impact assessment of public support for business R\&D has become crucial, as public aid for R\&D must compete in public budgets with other public spending items, and the final distribution is largely conditioned by a desire of governments to meet the demands of citizens. However, most databases used in the estimation of the impact of public support correspond to a specific moment of the business cycle. This fact prevents the comparison of the effects between periods of expansion and recession.

The objective of our study is to contribute to this analysis by comparing the effect of public support of business R\&D on technological performance before and during the recent economic crisis. One novelty of our study is that we focus on the effect of one specific instrument of direct public support: selective loans for firms' $R \& D$ projects. To do so, we use information provided by the CDTI, the main Spanish public agency that grants financial support to firms for the execution of R\&D projects. Specifically, we consider firms supported through CDTI programmes for the periods 2002-2005 and 2010-2012. The approach used concerning these instruments is also quite innovative, in the sense that we are aware of the features of the programmes 
throughout the entire period, and their evolution is taken into account for the interpretation of results.

To deal with selectivity and endogeneity problems that are usually present in this type of analysis, impact assessment is conducted using a combination of "matching" techniques and regression analysis. In a first stage, we estimate a probit model for the determinants of participation in CDTI programmes. The results of this estimation allow us to compute the propensity score needed to define the matched samples of non-participants for the two periods considered. Then, in a second stage, we use matched samples to analyse how this participation affects different technological inputs and outputs.

The results of the first stage suggest that, regardless of the period, being a continuous performer, export intensity and labour productivity increase the probability of participating in CDTI programmes, while the opposite effect is found for the presence of foreign capital. Interestingly, SMEs were more prone to participate before the crisis and less likely to participate during the recession. This is in line with the evolution of the number of innovative SMEs in Spain during the crisis, which decreased at a much higher percentage than innovative large companies. Another reason might be related to the increase in real guarantees required by the CDTI during the second period. Providing these guarantees is more challenging for SMEs; consequently, they must deal with an additional restriction.

As for the impact of participation on technological inputs, being awarded a CDTI loan increased the probability of self-financing R\&D 17.4 percentage points before the crisis, while the impact diminished to 9.7 percentage points during the period 2010-2012. Regardless of the period, the effect of having public support on the intensities of internal R\&D expenditures, total innovation expenditures, R\&D personnel and fixed capital investment was also positive. It is worth noting that estimated marginal effects for CDTI participation were quite similar between the periods 2002-2005 and 2010-2012, with the exception of the intensity in fixed capital investment. In this case, the effect was quite smaller during the crisis, which is consistent with the normative change in CDTI funding, which does not cover the purchase of physical assets as of 2008. However, the impact of CDTI support remained quite relevant during the crisis, which confirms the importance of public support in a period with a strong decrease in fixed capital investment in most Spanish firms.

Regarding technological outputs, being supported by public programmes clearly increased the probability of applying for patents before and during the crisis. However, the effect on process and product innovations differed according to the period considered. Participation in CDTI programmes increased the probability of achieving process innovations only before the crisis, while it enhanced the chance of obtaining product innovations only during the period 2010-2012. These results are again consistent with the normative change in CDTI funding concerning the purchase of physical assets, which is more relevant for process innovations. As a consequence, since 2008, supported firms seem to have focused more on obtaining product innovations.

According to these results, we can confirm that the effects of the CDTI aid are in line with the objectives of this organism in terms of increasing private activity in 
R\&D and contributing to the innovativeness of Spanish companies. The comparison between the two periods allows us to conclude that public support for R\&D can be considered a valuable instrument during recessions, in order to encourage firms to allocate private resources to activities with returns in the long or medium term.

This conclusion is in line with current trends in European public policies aiming to mitigate the negative effects of the Covid-19 pandemic. The Recovery Fund approved by the European Commission for the period 2021-2023 will support initiatives highly focused on the knowledge economy. Within this framework, most of the budget allocated to the Recovery Plan launched by the Spanish government (70\%) has been assigned to investments which demand a solid R\&D background: environmental solutions and digitalisation of the economy and society. For the first time, governments recognise that the instruments for combating the crisis are those that allow increasing knowledge and R\&D effort, and not penalizing these activities, which is fully coherent with the results of this paper.

Our study has some limitations. First, confidentiality rules of the Spanish Institute of Statistics prevent us from merging the information of the two periods considered for the analysis. Given that the features of CDTI programmes also changed between the periods 2002-2005 and 2010-2012, we cannot perfectly identify the relation between the effect of public support and the economic cycle. Second, our data restrictions also affect the information about the amount of loans awarded to each firm, so we can test only full crowding out of public funding on private R\&D investment. These limitations suggest a starting point for future lines of research.

Funding This research has been partially funded by the Spanish Ministry of Economy and Competitiveness (projects ECO2014-52051-R and ECO2017-82445-R) and by the Autonomous Region of Madrid through project S2015HUM-3417 (INNCOMCON-CM), co-funded by the European Social Fund (European Union). We are grateful to the CDTI for the data provided to carry out this research. The opinions expressed in this document are the sole responsability of the authors and do not necessarily represent the official position of the CDTI.

\section{References}

Aghion, P., Angeletos, G. M., Banerjee, A., \& Manova, K. (2010). Volatility and growth: Credit constraints and the composition of investment. Journal of Monetary Economics, 57(3), 246-265.

Aghion, P., Askenazy, P., Berman, N., Cette, G., \& Eymard, L. (2012). Credit constraints and the cyclicality of R\&D investment: Evidence from France. Journal of the European Economic Association, 10(5), 1001-1024.

Archibugi, D., Filippetti, A., \& Frenz, M. (2013). Economic crisis and innovation: Is destruction prevailing over accumulation? Research Policy, 42, 303-314.

Aristei, D., Sterlacchini, A., \& Venturini, F. (2017). Effectiveness of R\&D subsidies during the crisis: Firm-level evidence across EU countries. Economics of Innovation and new Technology, 26(6), $554-573$.

Barlevy, G. (2007). On the cyclicality of research and development. The American Economic Review, 97(4), 1131-1164.

Becker, B. (2015). Public R\&D policies and private R\&D investment: A survey of the empirical evidence. Journal of Economic Surveys, 29(5), 917-942.

Beneito, P., Rochina-Barrachina, M. E., \& Sanchis-Llopis, A. (2015). Ownership and the cyclicality of firms' R\&D investment. International Entrepreneurship Management Journal, 11, 343-359. 
Bovha-Padilla, S., Damijan, J.P., \& Konings, F. (2009). Financial constraints and the cyclicality of R\&D investment: evidence from Slovenia. LICOS Discussions Paper 239/2009. Katholieke Universiteit Leuven.

Brautzsch, H.-U., Günther, J., Loose, B., Ludwig, U., \& Nulsch, N. (2015). Can R\&D subsidies counteract the economic crisis? Macroeconomic effects in Germany. Research Policy, 44, 623-633.

Busom, I., \& Vélez-Ospina, J. A. (2020). Subsidizing innovation over the business cycle. Industry and Innovation. https://doi.org/10.1080/13662716.2020.1801388.

Cassiman, B., \& Veugelers, R. (2002). R\&D cooperation and spillovers: Some empirical evidence from Belgium. American Economic Review, 92(4), 1169-1184.

Censolo, R., \& Colombo, C. (2017). Cyclicality of the R\&D share of investment in the EU over the Period before and after the Crisis. Quaderno DEM 9/2017.

Cerulli, G. (2010). Modelling and measuring the effect of public subsidies on business R\&D: A critical review of the econometric literature. The Economic Record, 274(86), 421-449.

Cerulli, G., \& Potì, B. (2012). Evaluating the robustness of the effect of public subsidies on a firm's R\&D: An application to Italy. Journal of Applied Economics, 15(2), 287-320.

Colombo, M. G., Grilli, L., \& Murtinu, S. (2011). R\&D subsidies and the performance of high-tech startups. Economics Letters, 112(1), 97-99.

Cruz-Castro, L., Holl, A., Rama, R., \& Sanz-Menendez, L. (2018). Economic crisis and company R\&D in Spain: Do regional and policy factors matter? Industry and Innovation, 25(8), 729-751.

Czarnitzki, D., \& Hussinger, K. (2004). The link between R\&D subsidies, R\&D spending and technological performance. ZEW Discussion Papers 04-56.

Czarnitzki, D., \& Licht, G. (2006). Additionality of public R\&D grants in a transition economy: The case of Eastern Germany. The Economics of Transition, 14(1), 101-131.

Czarnitzki, D., \& Lopes-Bento, C. (2014). Innovation subsidies: Does the funding source matter for innovation intensity and performance? Empirical evidence from Germany. Industry and Innovation, 21(5), 380-409.

David, P., Hall, B., \& Toole, A. (2000). Is public R\&D a complement or substitute for private R\&D? A review of the econometric evidence. Research Policy, 29, 497-529.

Dimos, C., \& Pugh, G. (2016). The effectiveness of R\&D subsidies: A meta-regression analysis of the evaluation literature. Research Policy, 45, 797-815.

European Council. (2002). Barcelona European Council - Presidency Conclusions, March 2002. http:// register.consilium.europa.eu/pdf/en/02/st06/st06993.en02.pdf.

Eurostat. (2021). Community Innovation Survey. https://ec.europa.eu/ eurostat/web/ science-technology-inovation/data/database.

Fabrizio, K. R., \& Tsolmon, U. (2014). An empirical examination of the procyclicality of R\&D investment and innovation. The Review of Economics and Statistics, 96(4), 662-675.

García, A., \& Mohnen, P. (2010). Impact of government support on R\&D and innovation. UNU-MERIT Working Paper Series 2010-034, United Nations University, Maastricht Economic and Social Research and Training Centre on Innovation and Technology.

García-Quevedo, J. (2004). Do public subsidies complement business R\&D? A meta-analysis of the econometric evidence. Kyklos, 57(1), 87-102.

Guarascio, D., Pianta, M., Lucchese, M., \& Bogliacino, F. (2015). Business cycles, technology and exports. Economia Politica, 32, 167-200.

Heckman, J. J. (1979). Sample selection bias as a specification error. Econometrica, 47, 153-162.

Hud, M., \& Hussinger, K. (2015). The impact of R\&D subsidies during the crisis. Research policy, 44(10), 1844-1855.

Huergo, E., \& Moreno, L. (2017). Subsidies or loans? Evaluating the impact of R\&D support programmes. Research Policy, 46(7), 1198-1214.

Huergo, E., \& Trenado, M. (2010). The application for and the awarding of low-interest credits to finance R\&D projects. Review of Industrial Organization, 37, 237-259.

Huergo, E., Trenado, M., \& Ubierna, A. (2016). The impact of public support on firm propensity to engage in R\&D: Spanish experience. Technological Forecasting and Social Change, 116, 206-219.

INE (2009-2012). Innovation in Companies Survey. Instituto Nacional de Estadística. Madrid.

Laborda, J., Salas-Fumás, V., \& Suárez, C. (2020). An endogenous approach to the cyclicality of R\&D, investment under credit constraints: Firms' cash flow matters! Journal of Open Innovation: Technology, Market, and Complexity, 6(33), 1-23. 
Leuven, E., \& Sianesi, B. (2003). PSMATCH: Stata module to perform full Mahalanobis and propensity score matching, common support graphing, and covariate imbalance testing. Statistical Software Components S432001, Boston College Department of Economics.

Lööf, L., \& Nabavi, P. (2016). Innovation and credit constraints: Evidence from Swedish exporting firms. Economics of Innovation and New Technology, 25(3), 269-282.

López-García, P., Montero, J. M., \& Moral-Benito, E. (2013). Business cycles and investment in productivity-enhancing activities: evidence from Spanish firms. Industry and Innovation, 7(20), 611-636.

Makkonen, T. (2013). Government science and technology budgets in times of crisis. Research Policy, 42, 817-822.

Mand, M. (2019). On the cyclicality of R\&D activities. Journal of Macroeconomics, 59, 38-58.

Männasoo, K., \& Meriküll, J. (2014). R\&D, credit constraints, and demand fluctuations: Comparative micro evidence from ten new EU members. Eastern European Economics, 52(2), 49-64.

Pellens, M., Peters, B., Hud, M., Rammer, C., \& Licht, G. (2018). Public investment in R\&D in reaction to economic crises-a longitudinal study for OECD countries. In Discussion Paper No. 18-005, ZEW.

Perez, C. (2010). Technological revolutions and techno-economic paradigms. Cambridge Journal of Economics, 34, 185-202.

Peters, B., Dachs, B., Dünser, M., Hud, M., Köhler, C., \& Rammer, C. (2014). Firm growth, innovation and the business cycle. In Background report for the 2014 competitiveness report. (Tech. Rep.). ZEW Gutachten/Forschungsberichte.

Romer, P. (1990). Endogenous technical change. Journal of Political Economy, 5(2), S71-S102.

Rosenbaum, P. R., \& Rubin, D. B. (1983). The central role of the propensity score in observational studies for causal effects. Biometrika, 70(1), 41-55.

Rosenberg, N., \& Frischtak, C. R. (1984). Technological innovation and long waves. Cambridge Journal of Economics, 8(1), 7-24.

Takalo, T., Tanayama, T., \& Toivanen, O. (2013). Estimating the benefits of targeted R\&D subsidies. Review of Economics and Statistics, 9(1), 255-272.

Zúñiga-Vicente, J. A., Alonso-Borrego, C., Forcadell, F. J., \& Galán, J. I. (2014). Assessing the effect of public subsidies on firm R\&D investment: A survey. Journal of Economics Surveys, 28(1), 36-67.

Publisher's Note Springer Nature remains neutral with regard to jurisdictional claims in published maps and institutional affiliations. 